\title{
Using Blog Technology For Collaborative Learning Of Accounting And Corporate Governance Issues: Design And Implementation Of The Sarbanes-Oxley Blog
}

Guido L. Geerts, (E-mail: geertsg@lerner.udel.edu), University of Delaware Winifred D. Scott, (E-mail: winifred.scott@asu.edu), Arizona State University

\begin{abstract}
The main purpose of this paper is to provide design and implementation guidance to those interested in utilizing blogs as a collaborative learning tool in any given field of study. We created the Sarbanes-Oxley Blog (SoxBlog), a web-based forum for asynchronous student-instructor-expert collaboration. Given the recent scandals and publication of the Sarbanes-Oxley Act of 2002 (SOX), we increased our emphasis on integrating corporate governance and ethics issues into the financial accounting curriculum. Students new to financial accounting were asked to research a number of targeted issues related to the accounting environment and corporate governance and to discuss them with their peers, instructor, and experts. Some of the items to be discussed include: the relationship between task and learning objectives, students' engagement in the collaboration process, the structuring of the collaboration process, and the technological simplicity of creating and using blogs. Overall, students perceived the SoxBlog collaboration as a positive learning experience.
\end{abstract}

\section{INTRODUCTION}

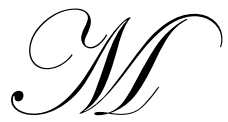

any new accounting students often think that financial accounting is just a lot of math. They have no idea of the concepts or issues underlying accounting choices made by business managers and standard setters in a complex economic, social, and political context (Kinney 2003; Arya et al. 2003). With the demise of Arthur Andersen in 2002 following the bankruptcy of Enron Corporation and other corporate scandals, as educators, we believe it is important to teach students about the complexities of economic, social, political, and ethical issues within the accounting environment. (Kinney 2003; PricewaterhouseCoopers 2003; Earley and Kelly 2004; Gaa and Thorne 2004; Jennings 2004; Wyatt 2004). We have adopted a blended learning approach to teach corporate governance issues in the introductory financial accounting class. The term blended learning basically means that different teaching methods are applied but is often used in the following, more specific, sense: "Blended learning systems combine face-to-face instruction with computer-mediated instruction" (Graham 2005). Our students used an asynchronous computer-mediated collaborative tool, the Sarbanes-Oxley Blog (SoxBlog), to discuss targeted issues related to the accounting environment, corporate governance, and the SarbanesOxley (SOX) Act of 2002 (U.S. Congress 2002). Asynchronous simply means that participants in the discussion do not have to be on-line at the same time.

In essence, a web log or blog is an electronic diary, a series of entries presented in reverse chronological order, published on the web, allowing readers to get the most recent information first. Blogging software, however, has become increasingly sophisticated allowing the creation of blogs that go well beyond the mere publishing of an electronic diary. Blogs are now used, among other things, as course management systems, knowledge management 
systems, and collaboration tools. Our technological objective was to create a web-based asynchronous collaboration tool for student-instructor-expert interaction on issues related to the accounting environment and corporate governance. We chose blogging software to implement our project. Neither of the authors of this paper used any asynchronous, computer-mediated, collaboration tools in their classes prior to this project. Blog technology presented itself as a free and easy-to-use solution. While there are other collaborative tools available (e.g., listservs and bulletin boards [Driscoll 1998]), in this study, we explore the integration of blog technology as a collaborative teaching tool in the classroom. The comparative analysis across web-based collaborative tools is saved for future studies.

We integrated the SoxBlog during the Fall 2005 semester into two accounting classes with business students that were generally new to financial accounting. The first class was "Introduction to Financial Accounting," a required undergraduate course for business majors. The second accounting class was "Financial Reporting and Analysis," a required core MBA graduate course. We thought it appropriate to apply the same SoxBlog learning objectives to both undergraduate and graduate courses since both groups of students lacked familiarity with financial statements, the reporting process, and corporate governance issues. However, while both classes were given the same assignment, we decided to create a separate discussion space for each class in order not to confound intangible student qualities. The SoxBlog for the undergraduate class can be found at http://soxblog207.blogspot.com while the SoxBlog for the graduate class can be found at http://soxblog800.blogspot.com. We reference the former website in this paper.

The actual creation of the SoxBlog occurred in two phases: design and implementation. Our focus during the design phase was on the creation of a task that helped accomplish the courses' learning objectives as well as the creation of incentives and guidelines to encourage and streamline students' engagement in the task. More specifically, we designed a task that required students to research and discuss open-ended questions regarding the accounting environment and corporate governance. During the implementation phase, we used blogging software (Blogger) to set up a collaborative asynchronous environment in support of the task. More specifically, we posted task materials on the SoxBlog websites, adapted their settings to our specific needs, and created student accounts.

The main objective of this paper is to provide "design and implementation guidance" to those instructors interested in utilizing blogs as a collaborative learning tool in any given field of study. The rest of the paper is organized as follows. The next two sections discuss the design phase and implementation phase of the SoxBlog. In section four, we discuss what we learned from designing, implementing, and running the SoxBlog: what went wrong and what could we have done differently. The final section presents the conclusions and some directions for future studies.

\section{THE DESIGN PHASE}

The design phase of the SoxBlog comprised the following two activities: (1) the design of a task and materials that help to accomplish the course's learning objectives, and (2) the design of guidelines and incentives to encourage and streamline students' engagement in the task.

Our goal was to have our financial accounting students gain an understanding of the economic-socialpolitical complexities that influence the accounting environment and governance of corporations. To accomplish our goal, we established seven learning objectives summarized in Table 1. Our strategy required students to research, compare, contrast, synthesize, and evaluate issues related to these learning objectives. To stimulate discussions, we designed fifteen open-ended questions that ask "how?" and "why?" and do not always have a single simple answer, rather, answers would often depend upon one's perspective. In Table 2, we list the learning objectives in the top row and the SoxBlog student questions by topic in the first column. When a question correlates with a learning objective, we indicated this by an $\mathrm{X}$ in the matrix table. The complete questions can be found at http://soxblog207.blogspot.com. 
Table 1

\section{Learning Objectives}

\begin{tabular}{|c|c|c|}
\hline \\
\hline \# & Keyword & Description \\
\hline 1 & $\begin{array}{l}\text { Accounting } \\
\text { Terminology }\end{array}$ & $\begin{array}{l}\text { Better understanding of basic accounting terminology including terms such as corporate } \\
\text { governance, reputation capital, audit committee, GAAP }{ }^{1} \text {, etc. }\end{array}$ \\
\hline 2 & $\begin{array}{l}\text { Qualitative } \\
\text { Characteristics }\end{array}$ & Better understanding of the qualitative characteristics that makes accounting information useful. \\
\hline 3 & $\begin{array}{l}\text { Economic, Social, } \\
\text { Political }\end{array}$ & $\begin{array}{l}\text { Better understanding of the economic, social, and political complexities that influence the } \\
\text { standard setters and the accounting environment. }\end{array}$ \\
\hline 4 & $\begin{array}{l}\text { Corporate } \\
\text { Governance - } \\
\text { Gatekeepers }\end{array}$ & To learn more about the gatekeepers and the roles they play in the corporate governance system. \\
\hline 5 & $\begin{array}{l}\text { New Law } \\
\text { The SOX Act of } \\
2002\end{array}$ & $\begin{array}{l}\text { To understand the provisions of the Sarbanes-Oxley Act (SOX) and how it is designed to restore } \\
\text { integrity and confidence of investors and users of the financial reports. }\end{array}$ \\
\hline 6 & $\begin{array}{l}\text { Ethical Decision- } \\
\text { Making }\end{array}$ & $\begin{array}{l}\text { To enhance the understanding of ethical decision-making of the gatekeepers in an accounting } \\
\text { context. }\end{array}$ \\
\hline 7 & Future & Consider the anticipated efficiency and future effectiveness of SOX. \\
\hline
\end{tabular}

Table 2

\begin{tabular}{|c|c|c|c|c|c|c|c|}
\hline \multicolumn{8}{|c|}{ Relating Learning Objectives (LO) to SoxBlog Student Questions } \\
\hline & $\begin{array}{c}\text { LO \#1 } \\
\text { Accounting } \\
\text { Terminology }\end{array}$ & $\begin{array}{c}\text { LO \#2 } \\
\text { Qualitative } \\
\text { Characteristics }\end{array}$ & $\begin{array}{c}\text { LO \#3 } \\
\text { Economic, } \\
\text { Social, } \\
\text { Political }\end{array}$ & $\begin{array}{c}\text { LO \#4 } \\
\text { Corporate } \\
\text { Governance - } \\
\text { Gatekeepers }\end{array}$ & $\begin{array}{c}\text { LO \#5 } \\
\text { New Law, } \\
\text { The SOX } \\
\text { Act of } 2002\end{array}$ & $\begin{array}{c}\text { LO \#6 } \\
\text { Ethical } \\
\text { Decision- } \\
\text { Making }\end{array}$ & $\begin{array}{l}\text { LO \#7 } \\
\text { Future }\end{array}$ \\
\hline \multicolumn{8}{|l|}{ PHASE I QUESTIONS } \\
\hline $\begin{array}{l}\text { Q1 Levitt \& Qualitative } \\
\text { Characteristics }\end{array}$ & $\mathrm{X}$ & $X$ & $\mathrm{X}$ & & & $\mathrm{X}$ & $\mathrm{X}$ \\
\hline Q2 Accountants & $\mathrm{X}$ & & $\mathrm{X}$ & $\mathrm{X}$ & & & \\
\hline $\begin{array}{l}\text { Q3 Board Of Directors } \\
\text { (BOD) }\end{array}$ & $\mathrm{X}$ & & $\mathrm{X}$ & $\mathrm{X}$ & & & \\
\hline Q4 Regulators & $\mathrm{X}$ & & $\mathrm{X}$ & $\mathrm{X}$ & & & \\
\hline Q5 Reputation Capital & $\mathrm{X}$ & $\mathrm{X}$ & $\mathrm{X}$ & $\mathrm{X}$ & & $\mathrm{X}$ & \\
\hline Q6 Market Reaction & $\mathrm{X}$ & & $\mathrm{X}$ & & & & \\
\hline \multicolumn{8}{|l|}{ PHASE II QUESTIONS } \\
\hline $\begin{array}{l}\text { Q1 SOX \& External } \\
\text { Auditors }\end{array}$ & & & $\mathrm{X}$ & $\mathrm{X}$ & $\mathrm{X}$ & $\mathrm{X}$ & $\mathrm{X}$ \\
\hline $\begin{array}{l}\text { Q2 SOX \& Internal } \\
\text { Auditors }\end{array}$ & & & $\mathrm{X}$ & $\mathrm{X}$ & $\mathrm{X}$ & $\mathrm{X}$ & $\mathrm{X}$ \\
\hline Q3 SOX \& Managers & & & $\mathrm{X}$ & $\mathrm{X}$ & $\mathrm{X}$ & $\mathrm{X}$ & $\mathrm{X}$ \\
\hline Q4 SOX \& BOD & & & $\mathrm{X}$ & $\mathrm{X}$ & $\mathrm{X}$ & $\mathrm{X}$ & $\mathrm{X}$ \\
\hline $\begin{array}{l}\text { Q5 Did Gatekeepers } \\
\text { Fail? }\end{array}$ & $\mathrm{X}$ & & $\mathrm{X}$ & $\mathrm{X}$ & & $\mathrm{X}$ & \\
\hline Q6 Role of Attorneys & & & $X$ & $X$ & & $\mathrm{X}$ & \\
\hline $\begin{array}{l}\text { Q7 Legal CEO } \\
\text { Motivation }\end{array}$ & & & $X$ & & & $\mathrm{X}$ & $X$ \\
\hline Q8 Why Fraud? & & $X$ & $\mathrm{X}$ & & & $\mathrm{X}$ & $\mathrm{X}$ \\
\hline $\begin{array}{l}\text { Q9 Restore Integrity? } \\
\text { Will SOX Be Effective? }\end{array}$ & & $\mathrm{X}$ & $\mathrm{X}$ & & $\mathrm{X}$ & $\mathrm{X}$ & $\mathrm{X}$ \\
\hline
\end{tabular}

Notice that in Table 2, we divided the topic questions into two phases. The purpose of the questions in Phase 1 was to familiarize students with accounting terminology and enable them to gain an understanding of key issues facing the accounting profession. The purpose of the questions in Phase 2 was to encourage students to evaluate the roles and responsibilities of accounting professionals and other gatekeepers in the corporate governance system.

${ }^{1}$ GAAP $=$ Generally Accepted Accounting Principles 
In sum, the design phase is where instructors first determine what it is that they want students to learn (the goal). Second, instructors develop and specify the learning objectives to accomplish the goal. Third, instructors create open-ended questions for students to explore various topics related to the learning objectives. Our strategy divided the topics into two phases, each with a specific purpose. Although we created fifteen questions and two phases, other instructors may choose any number of questions or phases to accomplish their own learning objectives. It should be noted that during the actual running of the SoxBlog, additional questions were added based on specific issues that emerged; e.g., a concept was not clear that needed further discussion, or a student raised an important topic that deserved its own discussion thread, etc.

Finally, instructors define task-related incentives, expectations, and guidelines to increase students' engagement and to facilitate the collaboration process. For the SoxBlog, grades were the key incentive for student engagement. The level of activity on the SoxBlog was worth twelve percent of the students' class grade. The grading policy (http://soxblog207.blogspot.com) provided students with an outline regarding our expectations: the level of activity (quantity) and the nature of their responses (quality). We asked students to make a minimum of ten meaningful comments: being involved in five different topics with at least one follow-up comment for each topic. The objective of follow-up comments was to trigger discussions among students. The idea of granting extra credit for a first responder entry was to make sure that (at least some) students would get engaged into the discussions early. The grading chart in Figure 1 helped students understand what the instructor meant by a meaningful comment (quality). A comment is meaningful when it is related to the question/issue and adds to the discussion. The grading policy was further designed to motivate students to search newspapers, journals, and the internet for articles related to the questions being discussed. For example, adding a link that challenged someone else's comment along with her own comment was considered a meaningful contribution since adding the link required the student to research the question. We also provided students with a timeframe chart (http://soxblog207.blogspot.com) to indicate the beginning and ending dates of each phase, making the deadlines for the project clear.

Figure 1

Grading Flowchart

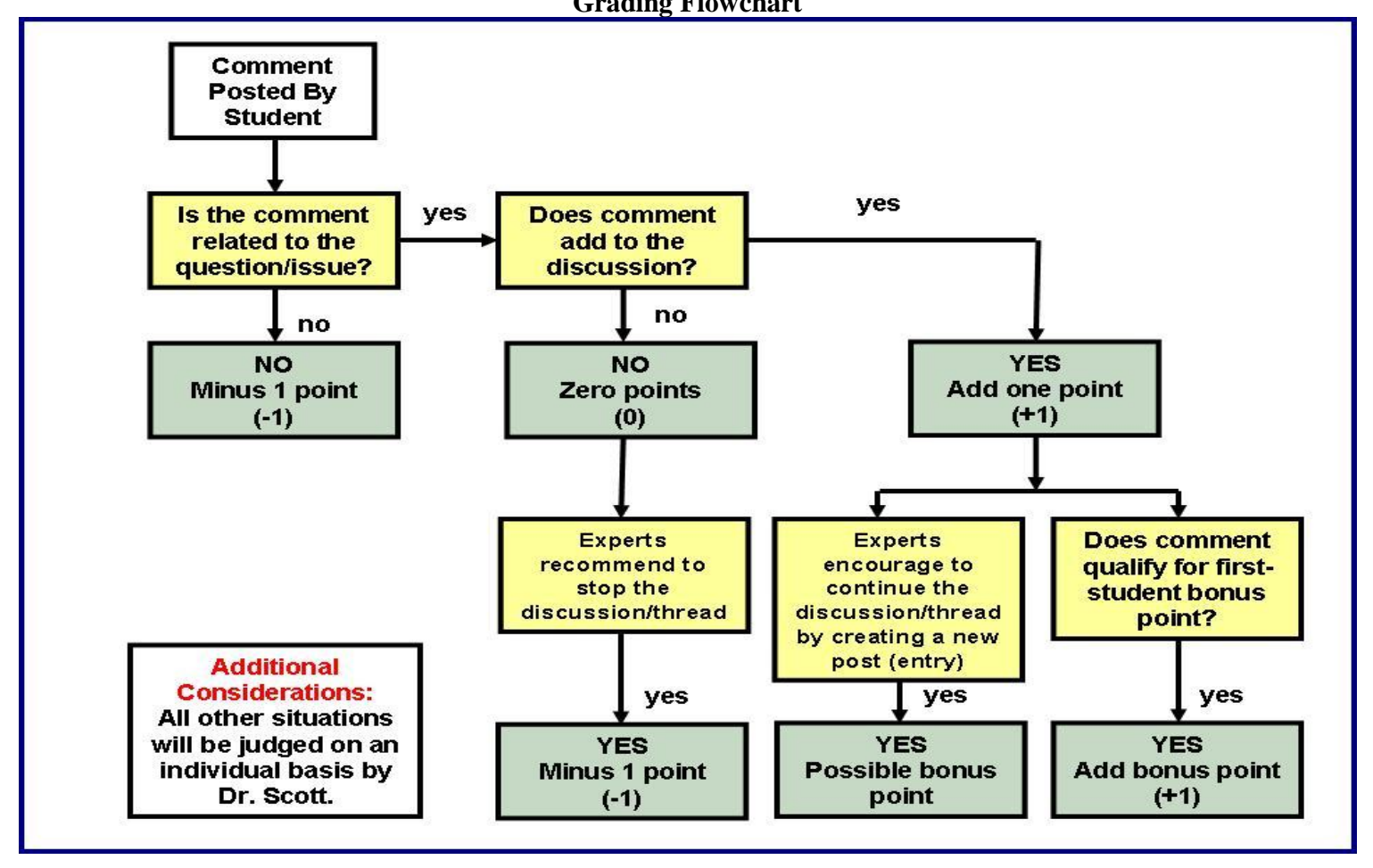


In addition, we created guidelines for lead-in, referencing, and etiquette issues to facilitate the discussions. For example, we provided students with suggested lead-in phrases to ease student collaboration such as the following.

\begin{tabular}{||c|c|}
\hline In contrast to______ (reference to comment or post; other reference) \\
\hline \hline In agreement with ___ (reference to comment or post; other reference) \\
\hline \hline
\end{tabular}

The objective of the referencing format was for students to clearly specify external references and to create links between discussions (threads). Finally, we provided students with some blogging "etiquette rules": (1) Use professional language and correct English; (2) Never plagiarize; (3) Be critical but not negative or offensive; and (4) Do not change your entries once you have submitted them. All of these materials were on-line for easy student access.

\section{THE IMPLEMENTATION PHASE}

A big part of the success of blogs is the availability of free and easy-to-use blogging software such as Blogger (www.blogger.com) and Spaces (spaces.msn.com). Blogging software allows for the uncomplicated creation and maintenance of a blog using menus and forms. For our purposes, the software needed to support (1) the setup of the SoxBlog and the delivery of task materials by the instructor, and (2) collaboration between students, instructors, and experts. We selected Blogger software, which was at the time we started this study, the most prominent blogging software, and readily available at no cost.

Blogger uses a post-and-comment format for collaboration. A post is a single entry in a blog and a blog is composed of multiple posts. A comment is a response to a post. A series of comments to a single post or topic is called a thread. Blogger lets you define who can create posts and who can create comments and therefore enables a variety of collaboration configurations. For the SoxBlog, we have chosen for a configuration where only the instructor (and experts) can create posts and thus open a topic for discussion. Students participated in the SoxBlog by responding to the posts through comments. We used interfaces similar to the one shown in Figure 2 to enter task materials, adapt the SoxBlog to our specific needs, and add students and experts as members to the SoxBlog.

Figure 2: Editing a Post

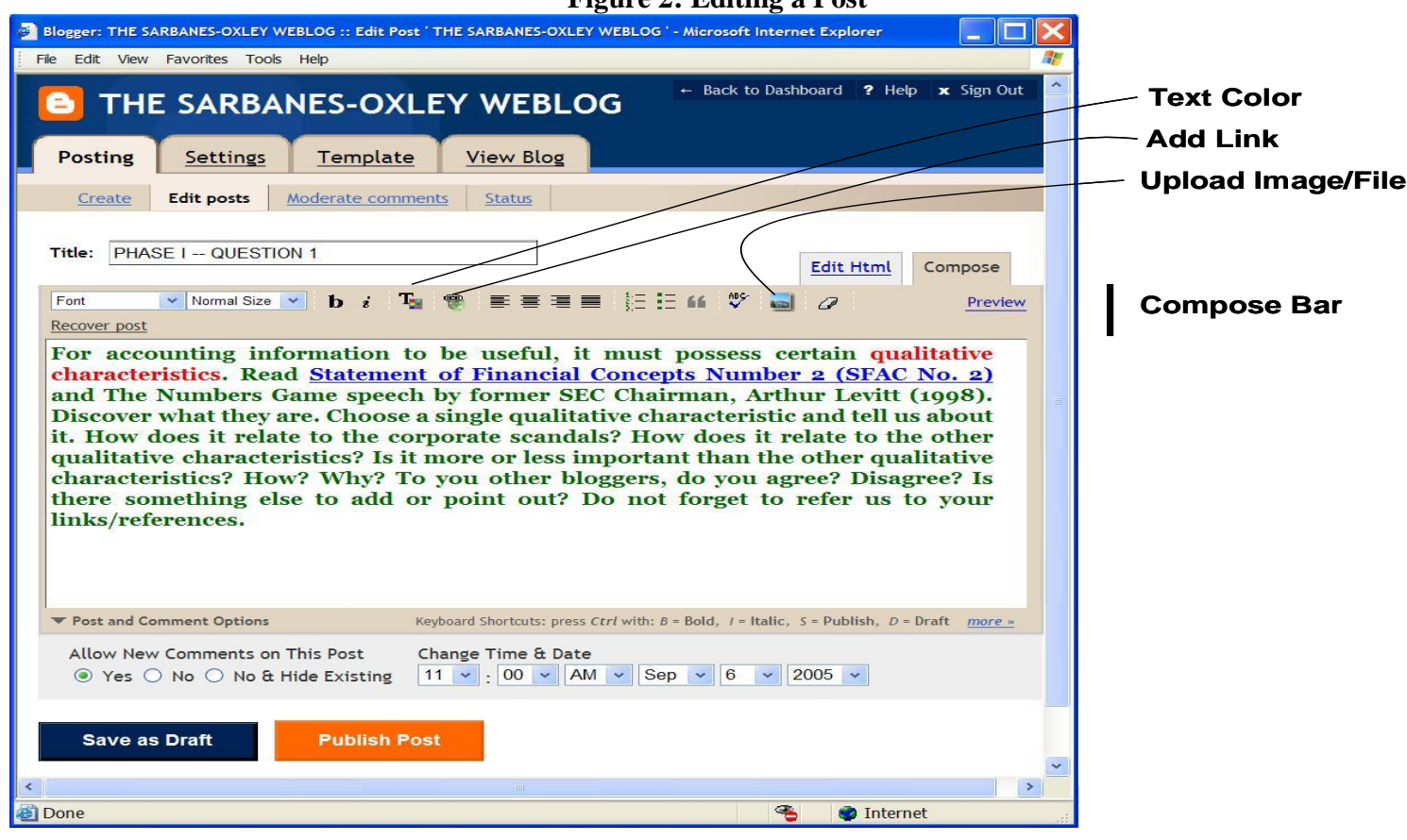


The editing and publishing of a post was relatively easy. Figure 2 shows the editing of a SoxBlog entry, the first question in Phase 1, with Blogger. The icons on Blogger's compose bar made it easy to integrate color, links, and graphs as part of a blog's content and to give it a web-page-like look. It sufficed to click the "Publish Post" button to update the blog with its new content. Figure 3 shows three entries or posts in the SoxBlog: an entry that shows the project's timeframe, an entry that provides links to the reading assignments for Phase 1, and an entry that represents the first question to be answered.

We further adapted the SoxBlog to our specific needs using Blogger's "Settings" menu, which contains interfaces similar to the one shown in Figure 2. The "Settings" menu allows, among other things, to: ${ }^{2}$

- $\quad$ Change general information such as the name of the blog.

- Determine where to put the blog. You can put your blog on Blogger's server (free of charge) or on your own server.

- $\quad$ Adapt the blog's appearance to your specific needs, such as how the date, time, and other information appear.

- Define the collaboration model: should a post have a thread, should the comments of a thread be shown, who should be able to comment on a post (i.e., anyone, or only registered users or blog members).

- $\quad$ Add members to the blog and assign them specific privileges.

- $\quad$ Set up e-mail addresses that notify members when a new post is added to the blog or to send out notifications when a comment on a post is made.

Although setting up the SoxBlog was menu-driven and easy to do, the following additional technological skills were required. First, we used additional software to transfer help and guidance manuals to a server. Second, some basic HTML skills were required for the implementation of the link section. The link section can be found on the middle-right side of the web page and points students to important materials such as the grading policies.

Following setting up the SoxBlog, we needed to invite students (and experts) to become members and to participate in the SoxBlog. Getting the students involved took place in a number of steps. We first created a member account for each student using the Members option in the Settings menu. Next, we sent each student an invitation by e-mail to join the SoxBlog. Students were asked to accept the invitation and create a Blogger account. Upon accepting the invitation, a student became a member of the SoxBlog, was granted permission to enter comments to the SoxBlog and engage in the asynchronous computer-mediated collaborative learning with classmates, experts, and instructor.

We provided students with technological guidance on how to use Blogger, and more specifically, the SoxBlog, for collaboration purposes. The manual explained the three main technological skills required by students: the creation of a Blogger account, joining the SoxBlog, and the creation of comments. The creation of comments, thereby participating in the collaboration process, was menu-driven and easy. Comments could be entered as plain text. Students could also use advanced text formatting and insert links, graphs, etc. which required some basic HTML skills. The SoxBlog manual contained a number of examples that illustrated the use of HTML for advanced text formatting and the insertion of links. If the manual did not contain the answer, then students were instructed to email the instructor to resolve their concern.

\footnotetext{
${ }^{2}$ See Castro (2005) for an in-depth technological discussion of Blogger.
} 
Figure 3

SoxBlog Posts

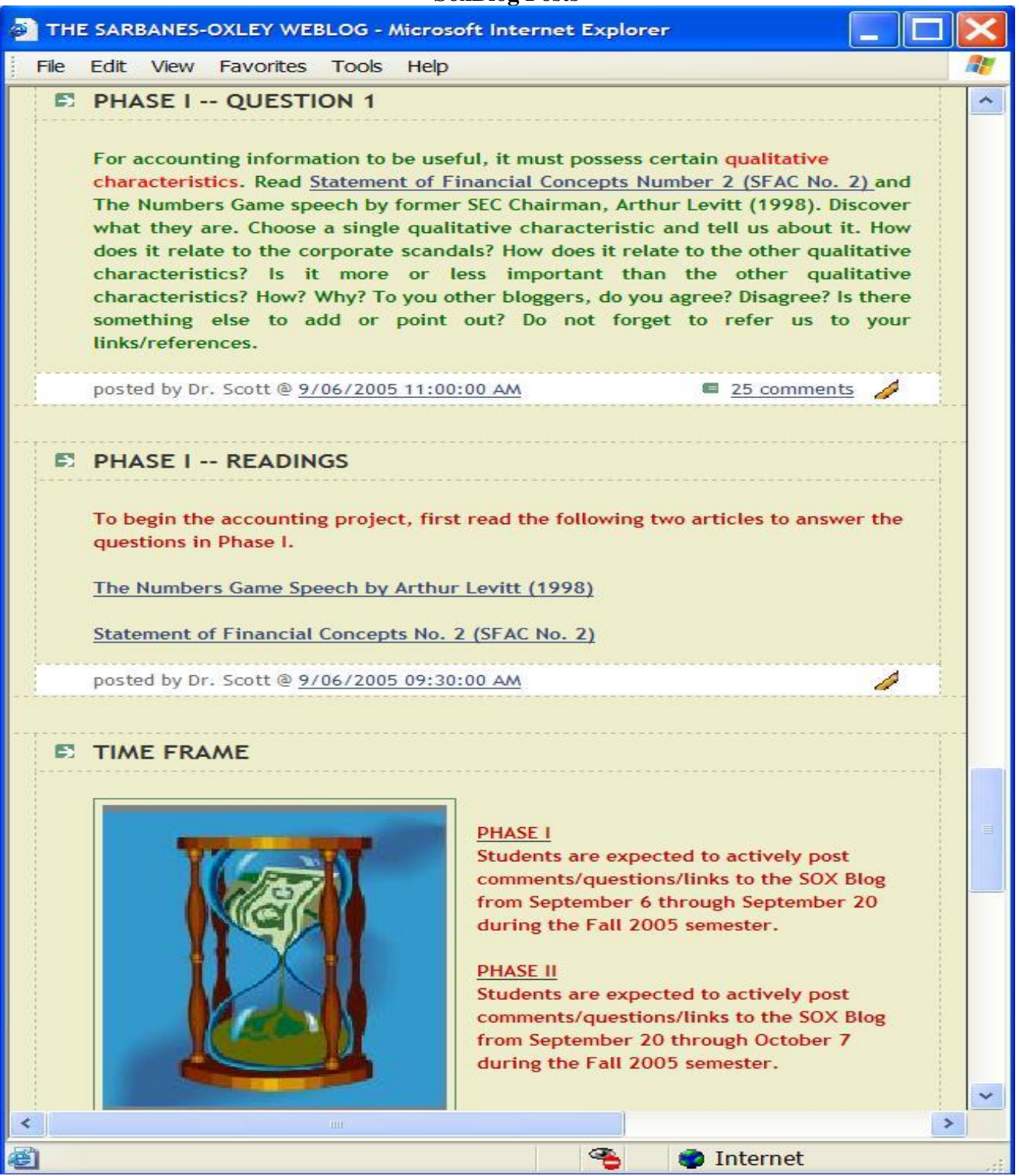

\section{LESSONS LEARNED}

The main objective of this paper is to provide "design and implementation guidance" to those instructors interested in utilizing blogs as a collaborative learning tool. This section reports on the lessons we learned from designing, implementing, and using the SoxBlog. What we learned includes students' feedback about the SoxBlog experience obtained through our post-SoxBlog student questionnaire. We first discuss some of the reasons why one should consider integration of blogs into the classroom. Following, we look at some issues that occurred and things that could be improved. 
Overall, students perceived the SoxBlog as a positive experience. Students could relate various issues to their careers, such as the corporate governance measures contained in SOX to minimize future accounting scandals and strengthen the integrity of the financial reporting process. Students also enjoyed the interaction with experts. The SoxBlog provided students with additional learning opportunities. Its asynchronous nature allowed them to read, reflect, and share information at their own convenience. The additional time allowed them to more carefully consider and provide evidence for their claims and provide deeper, more thoughtful reflections (Graham 2005). Another benefit of asynchronous learning was that it encouraged the participation of students who would feel less comfortable with face-to-face discussions in a traditional classroom setting. The public nature of the blog further required students to craft their responses more carefully - The whole world can read your contributions to the SoxBlog! The instructor also perceived the SoxBlog as a positive experience. In particular, the necessity to articulate the course objectives as part of the design activities was beneficial. Finally, from a technological point of view, the SoxBlog was easy to set up and use.

However, not all things went as planned: our expectations related to involvement were not always met, taskrelated design issues emerged, some guidelines were violated, and some minor technological problems occurred.

We expected that most students would get strongly involved in the discussions. As shown in Table 3, students meeting participation requirements for the graduate class reached 87 percent. However, students meeting participation requirements for the undergraduate class did not exceed 71 percent. In both classes, twenty-nine percent of the students exceeded the number of comments beyond what was required for grades. Future studies could consider other techniques, in addition to grades, that might stimulate full student engagement. The participation of our experts was also lower than expected. Experts reported "work time constraints" as the main reason for their limited participation. Future studies should consider using more experts and possibly assigning them to a limited number of questions. Further, the time commitment required from the instructor was higher than expected: designing the materials, being part of the discussions, and grading. Increased expert participation would lessen the instructor's participation time in the discussions. The grading process was especially time consuming since each comment needed to be evaluated individually for meaningful contributions. We do not see how the grading could be done much differently. It should be noted that the grading guidelines and the grading chart in Figure 1 made the grading process consistent and more effective. The instructor thought it was important to complete the grading of Phase 1 by the beginning of Phase 2 so that student-instructor feedback could be exchanged in the classroom.

Table 3

Number of Students Meeting and Exceeding Participation Requirements

\begin{tabular}{|c|c|c|c|}
\hline \multicolumn{2}{|c|}{$\begin{array}{c}\text { Undergraduate Students } \\
\text { Total }=41\end{array}$} & \multicolumn{2}{|c|}{$\begin{array}{c}\text { Graduate Students } \\
\text { Total }=31\end{array}$} \\
\hline Phase 1 & $\begin{array}{r}\text { Phase } 2 \\
\end{array}$ & Phase 1 & Phase 2 \\
\hline $\begin{array}{c}\text { Students meeting } \\
\text { participation requirements } \\
\mathbf{2 9} \text { or } \mathbf{7 1 \%}\end{array}$ & $\begin{array}{c}\text { Students meeting } \\
\text { participation requirements } \\
\mathbf{2 8} \text { or } \mathbf{6 8 \%}\end{array}$ & $\begin{array}{c}\text { Students meeting } \\
\text { participation requirements } \\
\mathbf{2 5} \text { or } \mathbf{8 0 \%}\end{array}$ & $\begin{array}{c}\text { Students meeting } \\
\text { participation requirements } \\
\mathbf{2 7} \text { or } \mathbf{8 7 \%}\end{array}$ \\
\hline $\begin{array}{c}\text { Of those } \mathbf{7} \text { (or } \mathbf{1 7 \%}) \\
\text { students exceeded maximum } \\
\text { participation points. }\end{array}$ & $\begin{array}{c}\text { Of those } \mathbf{1 2} \text { (or } \mathbf{2 9 \%}) \\
\text { students exceeded maximum } \\
\text { participation points. }\end{array}$ & $\begin{array}{c}\text { Of those } \mathbf{6} \text { (or } \mathbf{1 9 \%}) \\
\text { students exceeded } \\
\text { maximum participation } \\
\text { points. }\end{array}$ & $\begin{array}{c}\text { Of those } \mathbf{9} \text { (or } \mathbf{2 9 \%}) \\
\text { students exceeded } \\
\text { maximum participation } \\
\text { points. }\end{array}$ \\
\hline
\end{tabular}

Students reported a number of task-related design issues. Some of the questions were nested and it was not clear to students during Phase 1 whether they did or did not have to answer every part of a nested question to earn a point. This resulted in the first responder answering every part of the nested question, leaving several classmates believing that they were unable to make meaningful contributions to the discussion and earn points. The instructor posted a clarification regarding this issue on the blog during the task. The nested question issue was no longer an issue in Phase II. Students competed to become the first responder and earn the first responder bonus points. Consequently, a handful of students complained about the limited number of questions available and which limited 
their opportunity to gain first responder bonus point. One way to address this issue is by not nesting questions and, instead, post them as separate questions.

Students also violated some of our guidelines. For example, the SoxBlog guidelines instructed each student to enter their real name when accepting the invitation. However, a number of students violated this rule and used display names such as MJS and Huggie. In class, the instructor had to ask "Who is this?" by display name in order to identify the proper student and to give participation credit to the correct student for their posted comments. One possible explanation for violating this rule may be that students preferred a higher degree of anonymity; i.e., they did not wish to be recognized by their peers or anyone else reading the blog. Future studies may want to take this into consideration. One possible way to resolve this student anonymity issue is for instructors to pass around a "real name - display name" control list prior to sending out invitations. Also, the SoxBlog guidelines instructed students not to "change entries once they have been submitted" and to make corrections by adding an update section to the comment or by creating a new, properly stated comment. The rational for this restriction is the following. Foremost, it avoids references to non-existing comments. In addition, it further motivates students to craft their responses more carefully the first time. However, this guideline was frequently violated. Blogger software allows modifying or deleting comments at any time. Through student-instructor conversations, students explained that they feared poorly written comments might negatively affect their grade or would make them look bad to their peers and to outside readers. Students expressed great pride in displaying correct spelling and grammar in their written comments.

We encountered only one problem with the blogging software (Blogger). A few students and one expert had successfully enrolled as members of the SoxBlog but later received a message that they were not enrolled as members when they tried to create their first comment. For all cases, we solved the problem by creating a new account and inviting them again. We were not able to determine whether the problem was caused by a software bug or by a problem that occurred during the registration process. Experiencing only a single type of technological problem was lower than expected, especially since only a small percentage of students had previous blog experience. Only 11 percent of the graduate students and 24 percent of the undergraduate students had previous blog experience. While not a technological problem, both students and experts avoided the use of the more advanced technological skills discussed in the manuals, such as the use of HTML to add advanced formatting to the comments. Most opted to use plain text for communication purposes.

\section{CONCLUSIONS AND DIRECTIONS FOR FUTURE STUDIES}

We designed the SoxBlog as part of a blended learning approach to get students actively engaged in researching various topics related to the accounting environment and corporate governance. Our strategy required student on-line collaboration on these topics with peers, instructor, and experts, at their convenience. The creation of open-ended questions that were consistent with the instructor's learning objectives was an important aspect of the design phase. Use of the blogger software for publishing and editing of posts and comments was easy and readily available at no cost. According to our post-SoxBlog student questionnaire, overall, students perceived the SoxBlog as a positive learning experience.

However, we reported a number of lessons learned that might be valuable to other instructors who want to integrate blogs into their courses. We first reported some student, expert, and instructor involvement issues, and made some suggestions for improvement such as using more than three experts to interact with the students. Next, we discussed possible improvements in the task design. The instructor could minimize the number of nested questions and increase the number of posted questions available to students, thereby giving students more chances to earn the first responder bonus point. Following, we looked at guidelines violated by students and their rational for doing so. In the design phase, we did not consider whether students would prefer anonymity or not. Anonymity was a strong preference for a handful of the students. Instructors may want to give students an option by using a "real name display name" control list for the grading. Finally, we reported a minor technological difficulty with the Blogger software system. 
This study is exploratory in nature and many research issues remain to be addressed. One such issue is the effectiveness of blogs as learning tools and whether they are comparatively more effective than other asynchronous computer-mediated collaboration tools. A possible extension to the current study is to run the SoxBlog across different universities. Finally, blog technology is getting more advanced and future research projects might explore how such advances could support alternative learning strategies.

\section{REFERENCES}

1. Arya, A. A., J. C. Fellingham, and D. A. Schroeder. 2003. An academic curriculum proposal. Issues in Accounting Education 18(1): 29-35.

2. $\quad$ Castro, E. 2005. Publishing a Blog with Blogger. Berkeley, CA: Peachpit Press.

3. Driscoll, M. 1998. Web-Based Training: Using technology To Design Adult Learning Experiences. San Francisco, CA: Jossey-Bass/Pfeiffer.

4. Earley, C. E., and P. T. Kelly. 2004. A note on ethics educational interventions in an undergraduate auditing course: Is there an "Enron effect"? Issues in Accounting Education 19(1): 53-71.

5. Gaa, J. C., and L. Thorne. 2004. An introduction to the special issue on professionalism and ethics in accounting education. Issues in Accounting Education 19(1): 1-6.

6. Graham, C.R. (2005). Blended Learning Systems: Definition, Current Trends, and Future Directions. In Handbook of Blended Learning: Global Perspectives, Local Designs., edited by C.J. Bonk and C.R. Graham, 3-21. San Francisco, CA: Pfeiffer Publishing.

7. Jennings, M. M. 2004. Incorporating ethics and professionalism into accounting education and research: A discussion of the voids and advocacy for training in seminal works in business ethics. Issues in Accounting Education 19(1): 7-26.

8. Kinney, W. R. 2003. New accounting scholars - Does it matter what we teach them? Issues in Accounting Education 18(1): 37-47

9. PricewaterhouseCoopers. 2003. Educating for the Public Trust: The PricewaterhouseCoopers Position on Accounting Education. New York, NY: PricewaterhouseCoopers.

10. Wyatt, A. R. 2004. Accounting Professionalism - they just don't get it! Accounting Horizons 18(1): 45-53.

11. U.S. Congress. 2002. HR 3763 Sarbanes-Oxley Act 2002. Public Accounting Reform and Investor Protection Act.

\section{ACKNOWLEDGEMENTS}

We gratefully thank Stephanie Goodwin, Dave Conrad, and Harold Little for their willingness to participate in the SoxBlog discussions as experts. 